09 W SIS1 GOUDIE 8 a fin assigned ID 21345.

\title{
Internalising Survival Values into Science: Sustainability Implementation Science
}

\section{Key words:}

Urban sustainability, science, research, planning, methodology, energy, values.

Dr Douglas Goudie, Adjunct Lecturer \& Senior researcher, Centre of Tropical Urban and Regional Planning; School of Earth and Environmental Science James Cook University; Nth. Queensland, Australia.

Douglas.Goudie@jcu.edu.au

Human Geography theory allows for preferred human societal futures. This means the boundaries of science include valuing mitigation of global warming through Sustainability Implementation Planning.

Science discerns, processes, tests and incorporates changing reality. Human Geography theory acknowledges, as part of science theory evolution, that humans do care, that humans are agents of changing reality and that we have value and knowledge-based preferences of how our collective future may be influenced by our choices and resultant actions and impacts.

Climate change, disaster mitigation and sustainability implementation planning are linked aspects of an emerging value system in science: Sustainability Implementation Research (SIR). SIR starts with the value systems of Ecologically Sustainable Development, embraces the rigours of science replication and extends Action Research to take a whole-systems approach using the David Suzuki model. This defines long-term values, principles and processes to achieve sustainability. This paper draws on extensive disaster risk communication and community engagement research and consultancies by the author at Australian national, state and local government levels, with focus on Sustainability Implementation Planning (SIP) in North Queensland and James Cook University, described in this paper.

Understanding the degradation of 'the linear industrial model', of humanenhanced global warming; given a surveyed consensus that people want 'sustainable settlements', we can join values with emergent technologies to foster long-term local needs-meetings. Also, there are elements within organisations' authority chains which may resist complex change. Quantifying planning choices with science rigor via Sustainability Implementation Research (SIR) may help fearful decision-makers, although critical elements within 'the old way' of settlement planning do not want to lose power to 'the new way'. There is resistance to hierarchical command and control giving way to engaged participation in implementing sustainable structures and behaviour (Goudie 2005). This paper details rigorous and replicable values, principles and 
processes (VP\&P) to practice the emergent science of sustainability implementation, using Australian examples.

\section{A snapshot of Sustainability Implementation Science}

From a myriad of possibilities, we are an emergent species. With many impressive attributes, our rapid social evolution went into a 'starburst' when some ancestor-groups began to 'settle down' after the last ice age. These 'cultural hearths' have led, through often aggressive progress, directly to our current global complexities.

Geography, the oldest science (Homer $\sim 700 \mathrm{BC}$ ), considers people in time and space. SIP projects Geography forward with the values of Ecologically Sustainable Development (Bruntland 1987, IPA 1997) and provides SIR as a new methodological base (Goudie 2009). SIR includes, from the intellectual traditions of Human Geography (Walmsley 1988, Walmsley and Lewis 1993) a new kind of science (Withers 2007, Turner and Robbins 2008), where traditional science is combined with the values embedded in our survival urge and our abilities to plan: Sustainability Implementation Science (SIS).

This paper introduces SIS, providing the rationale and theoretical support for forward movement in our acceptance of changing reality and our role in it. This paper then provides examples of SIP, focused on $30 \mathrm{Ha}$ of surplus land to be part of a \$A1.3b upgrade of the Townsville campus of James Cook University, North Queensland, Australia. This will be marketed as Discovery Rise (DR). The project aspires to be a 'sustainability exemplar', leading to a 90-person workshop in August 2008 to describe what is needed to meet this aspiration.

For SIS, 'sustainability' values need to overrule 'linear consumption' beliefs and behaviours. This is a value laden statement, the new element in a science that can quantify, be reproduced and tested. Pretending humans do not care about the future ignores reality; the very foundation of science (Morrill 2002). Quantifiable issues deemed important in SIP include embodied energy and water, along with operating energy and water consumption. These consumption issues are central in SIP, where quality of life goals are wedded to ecologically sustainable development goals. We can conceptualise quality of life (QoL) and resource consumption (RC) can be expressed as a Sustainability Index of SI= QoL/RC (Royuela et al 2009, Plass and Kaltenegger 2007, Lebel and Lorek 2008). The SI of different planning scenarios can then be quantified and compared as a core SIP tool. In this way, SIP can be seen as a synthesis of the SIP methodology of clarifying overarching 'place' values, development principles which reflect the depth of ESD (Figures 1\&2) and the processes to achieve these defined goals with a calculation of physical and social preferred outcomes under the conceptual formula of $S I P=V P \& P * S I$, where VP\&P (Figure 2) is given a score scaled to achieve maximum long term urban wellbeing in dynamic balance with the remnants of nature. 
Figure 1 Why we do the things we do Stern's 1995 behavioural explanation model

Behaviour is explained by:

1. a person's position in a social structure,

2. with constraints and incentives as generators of values, which lead to

3. general beliefs,

4. world view,

5. specific beliefs and attitudes, generating

6. intent, which helps explains

7. behaviour.

Developed from Stern et al. (1995)

Figure 2 Values, Principles and Process for SIS

\begin{tabular}{|c|c|c|}
\hline \multicolumn{3}{|c|}{ 圈 } \\
\hline VALUES & PRINCIPLES & PROCESS \\
\hline $\begin{array}{l}\text { 1. ESD goals - Long- } \\
\text { term wellbeing } \\
\text { 2. End-user driven } \\
\text { 3. Place-based } \\
\text { 4. Seamless integration } \\
\text { 5. 'Evolve' local } \\
\text { expertise } \\
\text { 6. Inclusive and open- } \\
\text { ended planning } \\
\text { 7. "Tread gently" - life- } \\
\text { cycle analysis } \\
\text { 8. Equity \& integrity } \\
\text { 9. The centrality of } \\
\text { embodied and } \\
\text { operating energy and } \\
\text { water }\end{array}$ & $\begin{array}{l}\text { 1. Lead in urban sustainability } \\
\text { 2. 'Place' long term interests } \\
\text { design and behaviour goals } \\
\text { 3. Full quantification of } \\
\text { alternatives } \\
\text { 4. Localised needs-meeting } \\
\text { 5. Use local expertise, } \\
\text { knowledge and involvement } \\
\text { 6. Maximise local water, } \\
\text { energy and food focus } \\
\text { 7. Carbon neutral past peak oil } \\
\text { 8. Economic viability and } \\
\text { marketability } \\
\text { 9. Conduct full energy and } \\
\text { water use analysis }\end{array}$ & 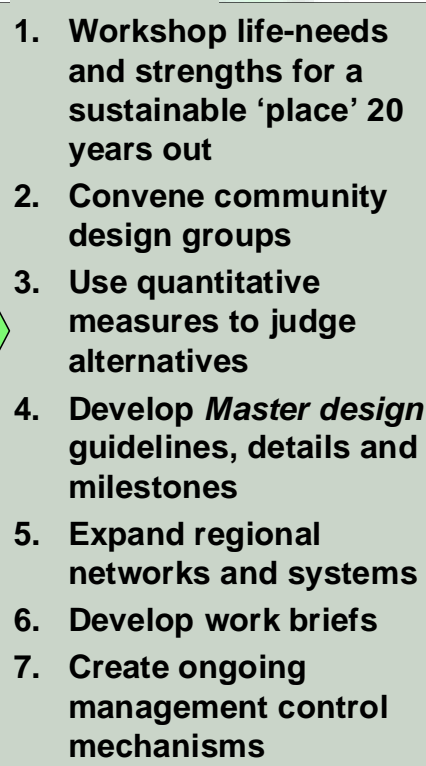 \\
\hline
\end{tabular}

Understanding the degradation resulting from the 'linear industrial model'; of human-enhanced global warming; given a surveyed consensus that people want 'sustainable settlements', we can join values with emergent technologies to foster long-term local needs-meetings. Impediments are as real as the use of science rigor in SIR. This paper details rigorous and replicable values, principles and processes to develop and practice the emergent science of sustainability implementation, using Australian examples. 
Key ESD values aim for long-term wellbeing and include equity and the precautionary principle. From the North Queensland experience, a core SIP value is that end-users want place-based design. Design and planning need to be seamless across all planning elements, with minimised earthworks, carbonfootprint and ecological disturbance generally. The workshop reported in this paper gave great support to using and nurturing local expertise. The key SIS decision filter is: What is likely to work in the long term $(20-200$ years +$)$, and what will clearly not.

An urgent SIP issue is fully reconfiguring our carbon energy relationships and greatly contracting our fossil fuel use. SIS becomes the negotiated and quantifiable detail of how to do this in time and space in social, political and economic realities. Institutional barriers to change (Goudie 2005, Morrill 2002, and Mendes 2008) are a distinct SIP impediment with quantification of alternative planning scenarios providing the lever for change.

\section{History and philosophy of Geography theory in science}

At the very roots of science epistemology (development), from the lliad (Homer $700 \mathrm{BC}$ ) onward, the study of human relationships with and in the environment is continuous and current (http://www.gutenberg.org/etext/6130).

Geographers sought 'legitimacy' as a scientists - understanding and explaining changing reality in ways that are observable and, ideally, reproducible - in the '60s, plunging into the quantitative (Bassett 1999). Science is perhaps a process, working in Kuhnian fits and starts of 'normal' science until the worldviews (paradigms) we embrace no longer fit the facts. Snedden (2002) argues that the technologies and place, from Galileo onward, help define science. Holding a self-evident falsehood that 'scientists or people generally are impartial' seems implausible. We do have values. Environmental values are central to environmental science theorists like Stern (1992, Fig 1). 
Stern's explanation of much human behaviour converges with Human Geography by understanding that social constructs and constraints influence nearly all people's interactions (Walmsley and Lewis 1993). ESD is social, cultural, environmental and economic long-term wellbeing. Like business-as-usual, the old way, 'sustainable planning intent' is also a social construct, based on knowledge, understanding and acknowledging values. The 90-person one day workshop held at James Cook University, Townsville north Queensland spent much time elucidating a placebased and end-user driven process to SIP, whilst a flow-on working group in July 2009 agreed Urban sustainability was the intent.

Joining traditional science with the sustainability values is a meeting of realist theory and sustainability practice, with nodes, networks and alliances central. Geographer's nodes and networks (ie Barnes 2004) and the developing SIP in North Queensland may be viewed as fractal images of theory changing into practice, at scales from when and where urban tomatoes are planted to how we use sugar cane or manage global fuel scarcity. SIS focuses on real people in the real world with real dynamics and needs, at all and every 'fractal' of scale. Endusers who care about the future are the SIS anchor, the main 'stakeholders' in sustainability.

This paper introduces and argues for a quantifiable methodology for sustainability implementation with the related SIR and SIS, seemingly appropriate at the Science in Society Conference, Cambridge in August 2009. The next section explains why Figure 1 is central to the frustration of many: why, with ESD public for so long, (Bruntland 1987), law and policy and decision-makers have remained reluctant to properly embrace the 'new' values and behaviours needed to achieve ESD. The short, 'empirical' explanation for resistance seems to be fear; fear of the new, the unknown by entrenched decision-makers and decision-making structures (Goudie 2005).

This paper, through SIS, SIR and SIP offers decision-makers the capacity to reproducibly quantify alternative planning scenarios, to research through the 'external' costs of development over its life-cycle, focused on the elements outlined in Figure 2, so that a rational, informed decision can be made to align planning with sustainability law and policy.

Figure 2 flags the obstruction and the way around: planning needs to start with values, overt, discussed, and based on consensus. We all want clean air, water and safety 20 years from now. We all want comfortable shelter and a sense of security. There is a long list of known shared needs and desires, including access, communication and mobility, social and cultural involvement. We value these things, so SIP starts with values, and then looks at what principles in planning will need to be met to embrace and further the realisation of those values. Finally, SIP outlines a clear (but flexible to place and end-users) process to achieve SIP aims, based on Urban Sustainability goals (Figure 3 ). 
Research which helps bring this about, including quantification of alternative scenarios is SIR, and the underlying methodology of linking physical well-being with social well-being is SIS. What distinguishes SIS from prior science theory is the Geographer's admission that we humans are part of the reality mix (Sarantakos 1994); that we do care, we do have preferences, and we can concern ourselves with the future. Geographers have dared reflect reality better than those who would pretend impartiality, objectivity.

\section{Paradigms}

Paradigms are a clear and embracing pattern, a coherent world view, a way of seeing social reality and gives cultural momentum (Dunlap and Van Liere 1978, Figure 1). The dominant social paradigm is defined by structures of power in society, with values where gross power and wealth imbalances are accepted as normal by nearly all society's members (Fien 1992, Arvidson 2009).

There is chasm in the dominant social paradigm, where continued loyalty to an organisation is more important than outcome focus. SIP aims to work toward lowimpact, localised permanent settlements (Nash 1989, Williams 1992, Rodger 1995, and Williams and Collins 1997). Government policy (AMCORD 1995) and urban theory (Mc Namara et al., 1993, Farrington 1992, Maher et al 1992, Newman and Kenworthy 1999, Greenway 2005) requires softening urban impacts on the environment.

\section{Values and science}

Analysing environmentally significant behaviour is complex and multi-disciplinary (Plass and Kaltenegger 2007, Lebel and Lorek 2008). While human geographers increasingly believe that 'value-free' research is unrealistic (Walmsley and Lewis 1993, Sarantakos 1994), other disciplines now embrace this 'reality' (Mendes 2008, Anderson 2009, Bdour et al 2009). Geographers Waddell and Nunn (1993) believe scientific detachment is impossible because all research has values, moral and ethical aspects and has social or environmental obligations. Research will always have much subjectivity, because there are many decisions made throughout the process. The admission of personal values is reassuring to 'social change' researchers wanting to help usher in ESD practice. It is permissible for geographers and others to admit personal future preferences, to take up advocacy for sustainability planning.

\section{Planning responsibilities flowing from peak oil}

SIS has the philosophical base and values of ESD, including public participation and dealing cautiously with uncertainty. Petroleum may be replaced by a sustainable energy source at equivalent or lower total costs, but we need to consider the changes needed in Westernised society if cheap and easily available renewable substitutes are not found.

'Future concern' values are not overtly those of reductionist empirical science, but intergenerational equity is a key principle of ESD, while energy planning is a 
key issue of intergenerational equity. How we use fossil energy now may have a profound effect on the choices people have by about 2012, when global petroleum demand may outstrip supply (Williams and Collins 1997, Campbell and Laherrere 1998, Goudie 2007, Fjerbaek et al 2009). As energy use occurs in a landuse and social context, peak oil becomes central to sustainability planning. Because language is central to world-views and values implementation, there are language issues to consider.

\section{Language concepts}

There are science word-concepts like Positivism - observe reality, then induce laws. Deduce implications/hypothesis; logically extend those laws, or critically rationalise that laws don't work. Perhaps human construct and contexts need to filter philosophising about the nature of changing reality. We are the lucky ape, and can abandon anthropocentric world views (Nash 1992). Science knows that reality existed before humans, and reality changes. This paper ushers in SIS: science as we knew it, joined by value systems evolved in seeking ESD.

We mainly use words to try to communicate from a source to recipients so that intended information is transferred and 'internalised' (Goudie 2005). What is science produces a seeming language perversion - a twisting of meaning to modernism, neo and post-isms (Bassett 1999). If science is the pursuit in understanding changing reality, realists seek underlying structures; rational abstractions (Bassett 1999). Neopragmatists may support Barnes who asserts that history, and thus science, is a series of ruptures, disjunctures and gaping non-sequiturs' (Barnes 1996 in Bassett 1999). We either mystify or simplify with words conveying our values. Rather than redefining the wheel, this reported Australian research indicates that urban sustainability is a verb.

Having set the conceptual framework to the 90-person workshop on sustainability aspirations for the JCU campus in Townsville, Australia reported in this paper, the following section describes workshop results. 


\section{Workshop results relating to urban sustainability Oral summaries}

These were presented to the University Vice-Chancellor and the Townsville Mayor for their comments. The following outputs focus on access and landuse, with full results at Goudie (2008b).

\section{Access needs for JCU's Discovery Rise to be a sustainability exemplar "Healthy people movement, a balanced community and holistic designs. A node in the wider Townsville network. Everything connected. Reinvigorating neighbourly environment. Our Oxbridge, moving to a town university, come for a reason. Bring the wider Townsville community to our campus. Zero carbon footprint, people have less reason to leave the site. Centre for sport, recreation, shopping. World leaders. Triple bottom line.}

Reliance on local resources - food, water, energy locally. Connecting university via: innovative transport system through all nodes. Create critical mass for the community hub, and create community. Self reliance with accommodation, food, recreation. University as a home. All services. All town needs; reliable public transport - perhaps light rail. Affordable housing. Need vibrancy and spaces for activities. Leadership in tropical research and implementation, not just research. Local food production, electrical fuel in parking bays."

\section{Written output}

"Creative pods/spaces throughout university and city with connection (physical or knowledge) between them. Complementary land use in addition to academic and residential e.g. conference facility. Control of the individual and overall built environment and use to maintain the master plan - mechanisms to preserve intent. Specific development codes to control built design; landscaping; density/height/lot sizes/site ratio; car parking. Empowering exchange within the wider community.

\section{Housing}

"No detached dwellings. Residential accommodation along corridors and nodes of medium and high density dwellings."

Infrastructure: water/food/nutrient; daily access; energy provision and use; outside links and access.

"Energy efficiency guidelines should consider: renewable energy; embodied energy. Linkages to broader community and infrastructure. Low carbon emissions (x 2) considering transport and energy use in buildings and in construction. Promote and maintain sustainable transport choices within the university and with the wider community."

\section{ACCESS}

"Car-free environment: bike and pedestrian networks internal and externalcommitment from all; maximum public transport; electric vehicles on site; public car park node; minimisation of roads/car park footprint. Cycle access routes weather-protected (x3); secured bike spaces at all buildings; User pay parking; 
Abolish fossil fuel transport within campus. Campus transportation to be low energy, human scale and convenient."

ENERGY

"Target of zero carbon footprint, including development phase. Topicality as well as research and Innovation - linked directly to industry and community; focus on sustainability."

Cohesion: people and activities - "Inviting, diverse and integrated, with overall integrity. Maintain community interaction. Integration and connectivity: bring uses together to overlap where possible. Vegetated; natural shaded and cooled water feature to reduce air temp; Design shall be on a human scale, not vehicle scale. University town - mixed uses and activities - integrated learning, research, work, commerce, community facilities, recreation, and agriculture/food production. Combine walking trails with environmental features. Must have design that responds to the local and regional, cultural, climactic environment."

\section{Cohesion: Landscape and buildings}

"High quality built environment and landscapes celebrating sense of place; Safety/security. All buildings to meet a "Green Star" rating (for tropics). All buildings sympathetic to tropical environmental conditions (x2). Embodied energy considerations in material use and recycle. Creative distributions of positive and negative spatial relationships; community gardens/composting. Low energy, climate responsive, low carbon footprint, suited to tropics. Buildings which maintain open space - open to high rise."

\section{Discussion}

\section{Developing Values, Principles and Processes (Figure 2)}

The values-driven approach to planning, refined and popularised by Suzuki (2009) informed the JCU conception of SIP, first practiced on Palm Island, near the Townsville coast (Goudie 2005), through a sustainable landuse planning process. Palm Island values were related to self-help, self-directed training, island building, financial independence and overall self-management.

The JCU workshop process and outcomes combine and resonate well with the sustainability implementation literature on many issues, such as integrating buildings, landscape and urban planning (Kerwin 2008, Eakin and Wehbe 2009). The sustainability VP\&P system (Figure 2) was embraced by workshop attendees, responding to global warming, peak oil, climate change, technical and communication advances, population and resource constrains, embracing advances in transport, energy and water issues, resource use and reuse. This parallels current global literature (Mitsch and Jorgensen 2003, Greenway 2005, Min et al 2007, Wang et al 2007, Plass and Kaltenegger 2007). 
The initiative shown by the University to convert sustainability intent into sustainability implementation through the workshop process has been unambiguous, with the first of six recommended focus groups beginning in July 2009. The following summarises how the workshop and the literature view the broad and defining issues of place-based sustainability.

\section{WEMFACS details}

WEMFACS grouping is arbitrary. Engineers and 'hard' scientists like logic, reductionism and order (Walmsley and Lewis 1993, Sneddon 2000). The WEMFACS grouping is supported by Bergen et al (2001), whose principles include design efficiency for energy and information. SIP means reductionism and pure logic are not the main planning building blocks. For Discovery Rise to be a sustainability exemplar, one group said the project needs: 'reliance on local resources - food, water, energy locally'. A high-order grouping can be: 'localising needs-meeting' across all settlement needs. New SIP groupings and power relationships are needed.

\section{Energy/environment/economics/engineering/education.}

Energy- The workshop asked for carbon neutrality and supported measuring and factoring in embodied and operating energy. The literature quantifies 'external energy' and other issues through "sustainability footprint" calculations, (Amekudzi 2009), life cycle analysis (Garcia-Serna 2007), using "real cost estimation" (Koo and Ariaratnam 2008) to include all building costs.

Engineering needs to have, according to participants 'exemplary standards for energy, water, resource use, non toxic use', pioneered by ecological engineering and 'green' chemistry (Bergen et al 2001, Mitsch et al 2003a\&b, Garcia-Serna et al 2007, Plass and Kaltenegger 2007, Koo and Ariaratnam 2008).

\section{Food}

Urban food production is important in SIP landuse. Community food gardens should be handy to water sources, organic waste generators; be on 'good' soils and be where people may want to do gardening. Food gardens should be around activity nodes, convenient to paths. Workshop groups said: 'Provide resources for local food production'. Local food production is synonymous with sustainability (Jarosz 2008, Yakubov 2009, Harris 2009, Mishkovsky 2009). Issues of 'food miles' (Lebel and Lorek 2008), peak oil and social networking are also important in the sustainability mix (Mendes 2008). Biomass for fuel is also likely to be part of sustainable urban futures (Laser et al 2009).

\section{Access}

Access and petroleum futures (Campbell and Laherrere 1998) and usual urban trips are inseparable from landuse (Goudie 2002). The workshop saw access as a core sustainability challenge. Discovery Rise will need: "Bike and pedestrian networks and minimised roads/car park footprint, within the university and in 
connection with the wider community; appropriate for users coming in and leaving the university." This is well aligned with developed urban planning theory (Newman et al 1995, Ryan and McNally 1995, Banister 1995, Lewis 1998, Goudie 2001, Amakudzi et al 2009, Anderson 2009).

\section{Culture/cohesion/commercial/Social}

The workshop said: "density must be determined. Social and cultural mix. Social; retail/commercial; arts/entertainment; recreation". Workshop attendees stressed the need to have ESD-focused building/landscape relationships. There is much intent and few examples of 'modern' ESD built environments (City of Melbourne 2008, Bergen et al 2008, Kerwin 2008, Li et al 2009). The workshop outcomes are aligned with global desire to avert 'business as usual'.

JCU's intent, like so many institutions and jurisdictions, aspires to sustainability (Goudie 2008a). Arvidsson (2009) argues that the needed qualities of innovation are about corporate settings which support creativity, nurturing and fostering links as shown in Figure 2 as a kind of collective intelligence. JCU have the intent, and there is clearly much regional 'collective intelligence' relating to sustainability implementation. The region, campus, staff and students may become 'world leaders' in SIP. 


\section{Quantifying development choices through VP\&P}

Evaluation of choices between business-as-usual and SIP will help implement SIP. Authors like Plass and Kaltenegger (2007) have developed Practical Evaluation Tools for Urban Sustainability, describing and quantifying core SIP issues for previously disparate stakeholders. Quantification leverages and rationalises 'the new way', with useful tools like a SIP Decision Support System.

Decision-makers are embedded in a car-centric world view (Newman and Kenworthy 1999). To help achieve sustainability, consider access, land use and home location as one issue to resolve via quantifying the lowest carbon footprint. This can be done with SIP VP\&P. This includes all overt and covert 'costs and benefits' (Troy et al 2003).

Measuring the Sustainability Footprint (Amekudzi et al 2009) with social and physical quality of life/social well-being parameters (Koo and Ariaratnam 2008) and factor in the full cost of a product or behaviour life-cycle (Greene 1992) will do this. SIR requires properly considering direct and indirect construction, social and remediation costs with quantification to minimise environmental impact and maximise economic and social capacity. The sustainability footprint of Amekudzi (2009) provides a good framework to quantify and thus be able to objectively compare the sustainability quotients of various scenarios.

Plass and Kaltenegger (2007) provide a decision support matrix linking decisionmaking components related to ESD application to compare alternative proposals. There are ways to measure alternate SIP scenarios. As an infant planning methodology, JCU can develop SIR quantification software, conceptually similar to software used to judge energy star rating for building operation.

Geographers compare economics in sustainability with the 'old' linear industrial model (get, use, throw away), providing a more 'organic' neoclassical circular flow model (Sneddon 2002). The emergent literature and the input from the Discovery Rise Paths to sustainability workshop indicate a need to measure all issues included in SIS. Figure 3 provides an early indicator of the issues in the SIS equation:

\section{Urban Sustainability Quotient $(S Q)=f(P) \times f($ WxExEuxEcxMxFxAxCuxSo) ..... Equation 1 (Figure 3).}

The conceptual rationale for this is provided in the introduction. The SQ will be one final and measurable indicator of sustainability, when all aspects are properly quantified, so alternative futures can be compared in a more objective way that has been the case since the industrial revolution. SQ = a function of Place $(P)$ in micro, macro and climatic detail; Water $(W)$, both embodied and operational, linked with nutrients and food production; Energy (E), embodied (construction) and operating; End users, (Eu) and their needs and wishes; Economic success $(E c)$; Management $(M)$, from land tenure to over sighting and controlling SIP; 
Food (F), Access (A, Banister 1996); Cultural (C) and Social (So) measures of long-term success.

With changing realities, management needs to anticipate and respond to sustainable end-user needs, using the VP\&P methodology to achieve sustainability. The science of human impact quantification is well evolved, e.g. www.footprintnetwork.org, The SI combines this with the 'carbon footprint and matured social indicator measures (ie Schwirian 1995, Royuela et al 2009).

Figure 3 SIS elements

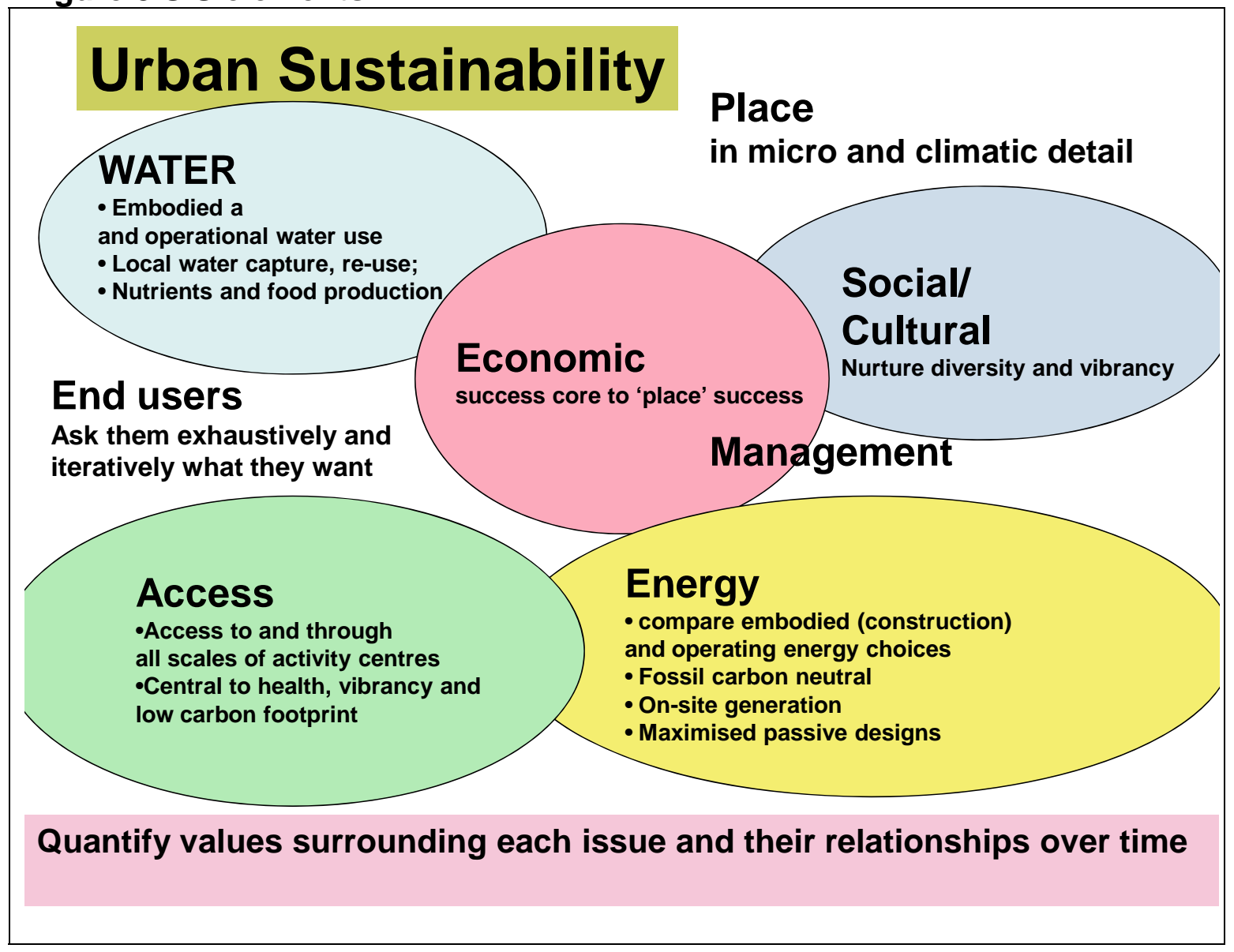

\section{Sustainability Implementation Planning is new and complex}

The SIP process is not straightforward or 'rational', as many would prefer (Plass and Kaltenegger 2007), partly explaining the institutional fear of SIP: it is complex, unknown and thus risky. There are 'process' conflicts in entering 'the new way' (Plass and Kaltenegger 2007). JCU intends to: 'Engage with industry and government' and: 'is a site and catalyst for innovation and understanding ... To be a global leader in environmentally sustainable infrastructure development (and) operation in the Tropics' (JCU 2008 Infrastructure objective 5). It would be easier to bypass issues raised in this article and continue with variants of business-as-usual; the linear industrial model and car-based development. 
Figure 4 summarises the key elements needed to attain SIP, linking the VP\&P, working down from defining values, important SIS principles, and what steps are needed to attain a systematic approach to work within known and knowable constrains into future centuries.

Figure 4 Sustainability Implementation Planning conceptual frame

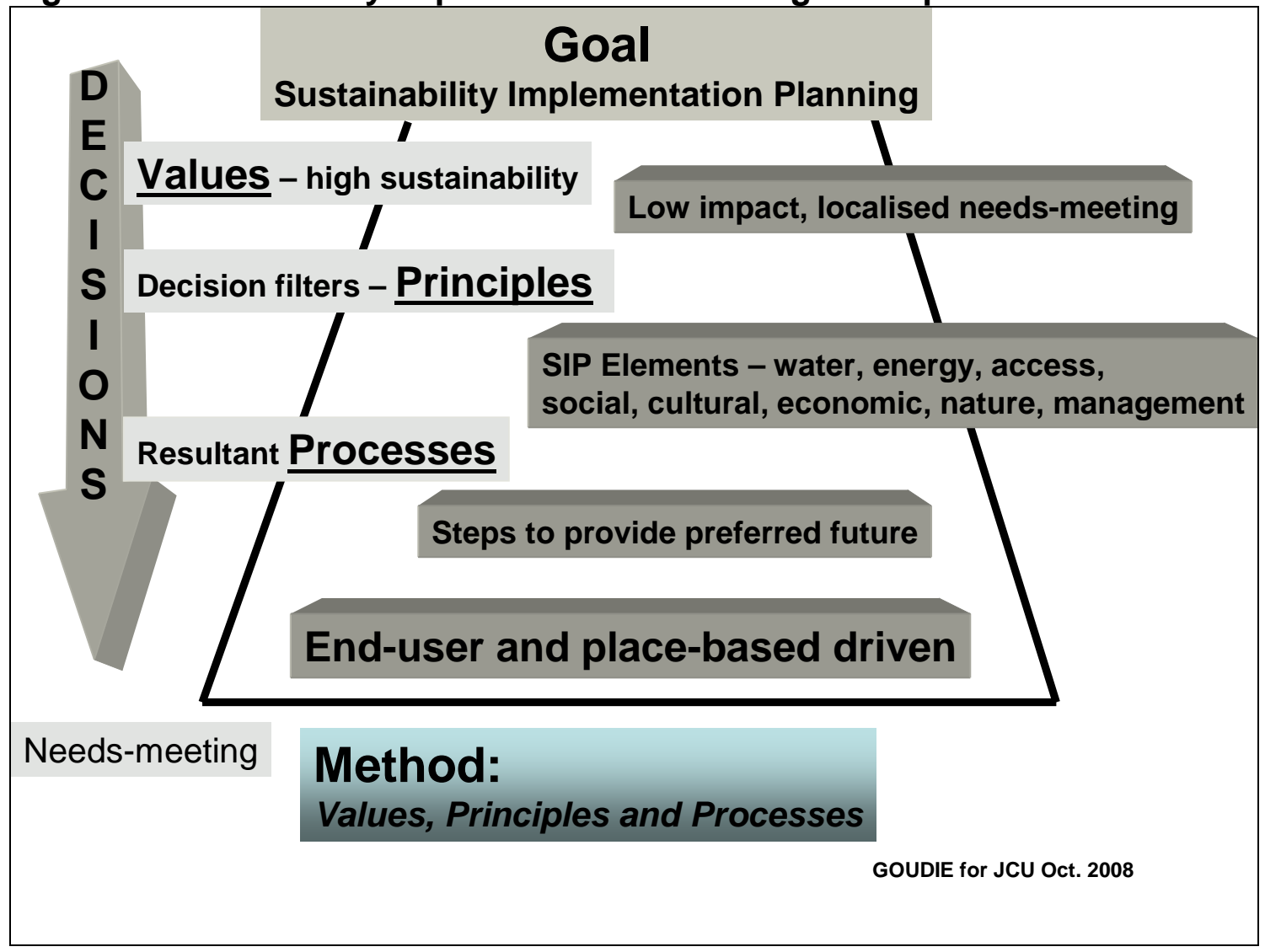

Next steps on the SIS path at JCU

JCU wishes to: "build on ... a research enriched environment ... The University is judged ... on its relevance and impact beyond academia." (JCU 2008). The University may develop six focus groups to oversee the interlocking complexities of SIP. JCU may engage with students and staff across all faculties and schools to have a 'living laboratory' in urban sustainability implementation, thus JCU may enhance teaching and research in this integrating and cooperative conceptual frame of SIS. Influential university decision-making groups may adopt the intellectual cohesion of the SIR process. This can then produce a unifying field where SIR theory permeates and shapes all facets of the university, from the education and undergraduate teaching schools to research foci for engineers, sociologists, forming new management and knowledge clusters. The above can build on the considerable 'regional intelligence' and goodwill already developed in North Queensland, drawing on sustainability planners, eco-engineers and 
environmental economists to develop SIS quantification algorithms, with ongoing engagement of our expanding planning student base.

JCU can capitalise on the broad regional leadership and goodwill to develop Discovery Rise as a seeding catalyst to expand regional networks, partners, knowledge clusters, synergies, skills and systems. Finally, all involved or interested in this SIR approach to planning can push for and actively contribute to 'the new way' in their own arenas, within this unifying quantifiable frame, where ever you are.

With the power of web access to 'now' information (Bruce 2007), SIS can be rapidly taken up, and success stories and methodologies shared. Human Geographers have long asserted that science operates on human values of what to research, how to go about the research, and how to present or use results. The macro-implication for our shared future is that science can expand to acknowledge shared values as a species, what matters to us on all scales into the future, and acknowledge too that we have the will and an emerging framework to develop sustainable settlements. Self-help and self-determinism are emergent values. In a worldview where all things are fractals of themselves, JCU may, by its innovation and integrity to its policies, help other institutions wed sustainability intent to SIS methodology to achieve preferred outcomes.

\section{Conclusions}

Sustainability implementation gains momentum across its many aspects, including landuse and people access to and through activity centres. From ecoengineering to social indicators of wellbeing and embodied energy calculations, urban sustainability strategies are becoming quantifiable. Thus planning choices can be compared. We now understand carbon and ecological footprints, but passing from sustainability intent to implementation has lacked a coherent intellectual frame. Without the paths to sustainability rationale of ESD values and the described methodology, there are few broad-scale examples of urban sustainability practice passing from laws and near-universal policy into on-ground reality. Sustainability Implementation Science provides the unifying and focusing approaches and tools for place-based and end-user-driven practice.

We have collective survival drives, forethought and planning ability. SIS provides a social, local expertise and institutional/political context to integrate sustainability implementation with the aspirations of societies to consciously 'go long term'. The SIS methodology defines what is needed and how to achieve urban sustainability.

Acknowledging that 'science' is a human construct and is 'value-laden', the definitions of science can expand to include values about our shared future as part of measurable and changing reality. SIS allows us to properly address the growing sense of the urgent need to properly manage and nurture local water, 
energy, access, social dynamics and remnant natural environments. James Cook University is at a leading edge of sustainable possibilities, perhaps capable of leading the largest 'living laboratory' in sustainability implementation planning in emergent technological settlements to date. There is institutional intent and perhaps administrative bravery. North Queensland, through state and local government, community, business and JCU, is well positioned to become a sustainability exemplar. The linear values of the old ways of planning are flawed. The long-term values we share can be incorporated into a coherent methodological framework and approach to develop viable, long-term and interconnected local urban futures.

\section{Acknowledgements}

Ongoing thanks to A. Professor, David King, Director of the Centre for Tropical Urban and Regional Planning, School of Earth and Environmental Sciences, JCU. David has nurtured my unruly, headstrong and evolving way of viewing the world, encouraged during my childhood. This emerging world view has been under David's guidance since 1992, through various higher degrees, teaching duties, post docs. and consultancies.

A large thank you to JCU's Facilities Management Office who approached me in 2007 to help with DR achieving exemplar status. Brave and far-sighted people. This description includes our Vice Chancellor and Pro-VC at JCU. Appreciated. Large thanks to the 10-person working group I was privileged to chair; meeting for months to have the workshop happen with such focus and productivity. The Centre for Excellence in Tropical Design were main partners in this and other regional sustainability undertakings Thanks to the facilitator, Professor $V$ Brown, and all attendees with their wealth of drive, experience and vision. Largest thanks go to each of the 90 people at the workshop for the disparate but unified input to the day and the future.

\section{Goudie's biographic SIS notes}

Douglas had one great-grandmother, president of her suffragette group in the early 1900s in Melbourne. He grew in a family where one grandfather was the only farmer not to clear around his river banks in the 1940s in Victoria. Douglas is a product of his cultural sheath (Fig 1). Cub and scout, member of the Melbourne Conservation of urban energy group in the 70's, his Botany degree from Melb university could not find him work in bio-conversion, so he was a labourer for many years. One sore back later, then three higher degrees in urban energy in North Queensland, Douglas was active in conservation and founding Chair of the Townsville Urban production and land care group in the early 90 s. An active cyclist advocate, Douglas has had numerous government and other consultancies on sustainability in risk communication and planning.

Being asked to lead the workshop process, including the workshop day, were his most fulfilling times in years. Douglas is an Adjunct lecturer and senior researcher in the Centre for Tropical Urban and Regional Planning in the School 
of Earth and Environmental Sciences at JCU, and Principal of Sustainable Structures and Behavior, a Consultant for hire - Douglas.Goudie@jcu.edu.au 


\section{References}

AMCORD 1995. AMCORD95. Department of Housing and Regional Development. Aust. Govt. Printing Service.

Amekudzi AA, Khisty CJ, Khayesi M 2009. Using the sustainability footprint model to assess development impacts of transportation systems. Transportation Research Part A 43 (2009). 339 - 348.

Anderson C 2009. Saving the Environment: Five Creative Approaches. The Futurist. 43:2. $48-51$.

Arvidsson A 2009. The ethical economy: Towards a post-capitalist theory of value. Capital \& Class; 97. $13-29$.

Banister D 1996. Energy, quality of life and the environment: the role of transport. Transport reviews 16:1. 23 - 35.

Barnes TJ 2004. The Progress in Human Geography lecture Placing ideas: genius loci, heterotopia and geography's quantitative revolution. Progress in Human Geography 28, 5 (2004) pp. 565-595.

Bassett K 1999. Is there progress in human geography? The problem of progress in the light of recent work in the philosophy and sociology of science. Progress in Human Geography 23,1 (1999) pp. 27- 47.

Bdour AN, Hamdi MR and Tarawneh Z 2009. Perspectives on sustainable wastewater treatment technologies and reuse options in the urban areas of the Mediterranean region. Desalination. 237:1-3. Pp162 -174.

Bergen SD, Bolton SM and Fridley JL 2001. Design principles for ecological engineering. Ecological Engineering 18(2001). 201-210.

Bruce GA 2007. A Sustainable Tropical City of the Future. The international journal of environmental, cultural, economic and social sustainability. Http://www.Sustainability-Journal.com. Melbourne, Australia by Common Ground Publishing Pty Ltd. Www.commongroundpublishing.com. 3:6, 85-95.

Bruntland G (Ed) 1987. Our Common Future. World Commission on Environment and Development. Oxford England. Oxford University Press.

Campbell CJ and Laherrere JH 1998. The end of cheap oil. Sci. Am. 3:278, 60-65.

City of Melbourne 2008. Council House 2. http://www.melbourne.vic.gov.au/info.cfm?top=171\&pg=1933

Dunlap RE and Van Liere KD 1978. The 'new environmental paradigm': a proposed measuring instrument and preliminary results. J. of Envtl. Ed. 9:4, 10 -19.

Eakin HC and Wehbe MB 2009. Linking local vulnerability to system sustainability in a resilience framework: two cases from Latin America. Climatic Change. 93:3-4. 355 $-378$.

Farrington J 1992. Transport, environment and energy. In (Ed) BS Hoyle and RD Knowles Modern transport geography. Wiley and sons.

Fien J 1993. Education for the environment- critical curriculum theorising and environmental education. Deakin University.

Fjerbaek I, Christensen KV, and Norddahl B 2009. A Review of the Current State of Biodiesel Production Using Enzymatic Transesterification. Biotechnology and Bioengineering, 102:5, 1298 - 1315.

Garcia-Serna J, Perez-Barrigon L and Cocero, MJ 2007. New trends for design towards sustainability in chemical engineering: Green engineering. Chemical Engineering. 133:1-3. 7-30.

Ghosh S, Vale R and Vale B 2009. Local food production in home gardens: measuring on-site sustainability potential of residential development. International Journal of Environment and Sustainable Development. 7:4. 430-451. 
Goudie DD 1995. Sustainable Domestic Energy Use in North Queensland. MSc Thesis. North Queensland Collection. James Cook University Townsville. http://eprints.jcu.edu.au/377/ ).

Goudie D 2001. Toward Sustainable Urban Travel. PhD thesis. James Cook University. http://eprints.jcu.edu.au/967/

Goudie D 2002. Zonal method for urban travel surveys: sustainability and sample distance from the CBD. Journal of Transport Geography 10: 287 - 301. Elsiever. http://Www.sciencedirect.com/science?_ob=ArticleURL\&_udi=B6VG8-454HFP3$3 \& \_u s e r=972264 \& \_r d o c=1 \& \_f m t=\& \_o r i g=s e a r c h \& \_s o r t=d \& v i e w=c \& \_a c c t=C 000049$ $659 \&$ version $=1 \& \_$urlVersion $=0 \& \_$userid $=972264 \& m d 5=2508 c 380 c 0 d 8 b b e 8 b b 6 a 22$ $5 d 5969 a 93 d$

Goudie DD 2005. Consultant's Draft Version 3a Palm Island - Sustainability Landuse Plan for broad discussion and feedback. SEES. http://www.tesag.jcu.edu.au/Library/secure/pi_plan/contents.html

Goudie DD 2007. Peak oil, planning, paths and passing paradigms. Queensland Planner 47:4. 9-13.

Goudie DD 2008a. Paths to sustainability implementation planning. Discovery Rise, JCU Townsville: Report 1 Review of others' sustainability efforts. 38. http://www.ees.jcu.edu.au/cturp/DR_Rev_1.htm

Goudie DD 2008b. Discovery Rise, James Cook University, Path to Sustainability. 2008 Workshop and next steps. Parts $1-3$ :

http://www.ees.jcu.edu.au/cturp/08\%20DR\%20Rpt\%202\%20B/08\%20DR\%20Report $\% 202 \% 20 P t \% 201 \% 20 d . d o c$

http://www.ees.jcu.edu.au/cturp/08\%20DR\%20Rpt\%202\%20B/08\%20DR\%20Report \%202\%20Pt\%202\%20c.doc

http://www.ees.jcu.edu.au/cturp/08\%20DR\%20Rpt\%202\%20B/08\%20DR\%20Report \%202\%20Pt\%203\%20a.doc

Appendix:

http://www.ees.jcu.edu.au/cturp/08\%20DR\%20Rpt\%202\%20B/08\%20DR\%20Report \%202\%20xAppendix\%201\%20a.doc

Goudie DD 2009. Evacuation as a Communication and Social Phenomenon. In (Ed) RA Meyers. Encyclopedia of Complexity and Systems Science. 3109 - 3142. SpringerScience+BusinessMedia, LLC.

Greene D 1992. Overview of Least Cost Planning. 1st National demand management conference - focus for the future. Electricity Supply Association of Australia. 813-821.

Greenway M 2005. The role of constructed wetlands in secondary effluent treatment and water reuse in subtropical and arid Australia. Ecological Engineering. 25:5. 501509.

Harris E 2009. The role of community gardens in creating healthy communities. Australian Planner, 46:2. 24-27.

http://www.legislation.qld.gov.au/Bills/53PDF/2009/SusPlanB09.pdf

Homer ( 700 BC) The Iliad. Translated by A Pope, 1899. http://www.gutenberg.org/etext/6130 .

IPA 1997. The Integrated Planning Act. Queensland Government.

Jarosz L. 2008. The city in the country: Growing alternative food networks in Metropolitan areas. Journal of Rural Studies. 24:3. 231 - 244.

JCU 2008. University Plan. http://cms.jcu.edu.au/idc/groups/auth/documents/corporate_plan/jcuprd_025575.pdf Kerwin T 2008. Building Tall (And Designing Deep) In China. The Architectural Review. 224:1337. 78 - 80. 
Koo DH and Ariaratnam ST 2008. Application of a Sustainability Model for Assessing Water Main Replacement Options. Journal of Construction Engineering and Management. 134:8. 563 - 574.

Laser M, Larson E, Dale B, Wang M, Greene N and Lynd LR 2009. Comparative analysis of efficiency, environmental impact, and process. Economics for mature biomass refining scenarios. Biofuels, Bioprod. Bioref. 3. 247-270.

Lebel L and Lorek S 2008. Enabling Sustainable Production-Consumption Systems. Annual Review of Environment and Resources. 33:1. 241 - 275

Lewis SL 1998. Land use and transportation: envisioning regional sustainability. Transport Policy. 5(1998) $147-161$.

Li XP, Manman C and Anderson BC 2009. Design and performance of a water quality treatment wetland in a public park in Shanghai, China. Ecological Engineering. 35:1. $18-24$.

Maher C, Whitelaw J, Mc Allister A, Francis R, Palmer J, Chee E and Taylor P 1992. Mobility and locational disadvantage within Australian cities: social justice implications of household relocation. Melbourne Office, Australian Bureau of Statistics. AGP.

Mendes W 2008. Implementing Social and Environmental Policies in Cities: The Case of Food Policy in Vancouver, Canada. (Report). International Journal of Urban and Regional Research. 32:4. $942-967$.

McNamara B, Croft $P$ and Cooper M 1993. Integrated environmental road planning: a policy perspective. In (Ed) R Freestone. Spirited cities. Urban planning, traffic and environmental management in the nineties. The Federated Press.

Min W, Jingsong and Rusong W 2007. Ecological engineering for water in sustainable settlements construction. International Journal of Sustainable Development and World Ecology; 14:6. 556 - 574.

Mishkovsky N 2009. Support the Farm Stand To Feed "Locavores" And the Economy. Public Management. 91:2. $24-28$

Mitsch WJ, Zhang L, Anderson, CJ, Altor AE and Hernandez ME 2003a. Creating riverine wetlands: Ecological succession, nutrient retention, and pulsing effects. Ecological Engineering. 25:5. 510-527.

Mitsch, WJ and Jorgensen SE 2003b. Philosophy and Emergence of Ecological Engineering. Ecological engineering: A field whose time has come. Ecological Engineering 20:5 $363-377$.

Morrill R 2002. Theory and synthesis. Progress in Human Geography. 26:1 113-115.

Nash R 1989. The Rights of Nature. Primavera Press. The Wilderness Society. Tasmania.

Newman P, Kenworthy J and Vintile P 1995. Can we overcome automobile dependence? Physical planning in an age of urban cynicism. Cities. 12:1 $53-65$. Elsevier Science Ltd. GB.

Newman PW and Kenworthy JR 1999. Sustainability and cities. Overcoming Automobile dependence. Island Press, Washington DC. 442.

Plass N and Kaltenegger I 2007. Strategic and Practical Implications in Decision Making and Planning for Sustainability. Indoor and Built Environment 16:3. $204-215$.

Queensland Government 2009. Sustainable Planning Bill (Draft at Aug '09)

Rodger A 1995. Urban design issues: achieving livable and sustainable cities. In (Ed) DHRD Urban form, urban design and energy use. Better cities occasional papers series 2, paper 3 AGPS.

Royuela V, Roman J and Artı M 2009. Using Quality of Life Criteria to Define Urban Areas in Catalonia. Soc Indic Res. 90:419-440.

Ryan S and McNally MG 1995. Accessibility of neotraditional neighbourhoods: a review of design concepts, policies, and recent literature. Transpn. Res. A. 29A:2 87 - 105. 
Sarantakos S 1994. Social research. Charles Stuart University.

Schwirian KP, Nelson AL and Schwirian PM 1995. Modeling urbanism: economic, social and environmental stress in cities. Social indicators research. 35:2, 201-223.

Sneddon C 2000. 'Sustainability' in ecological economics, ecology and livelihoods: a review. Progress in Human Geography. 24:4. 521 - 549.

Stern P 1992. Psychological dimensions of global environmental change. Annu. Rev. Psychol. 43, 269 - 302.

Stern PC, Dietz T and Guagnano GA 1995. The new ecological paradigm in socialpsychological context. Environment and behaviour. 27:6, 723 - 743.

Suzuki D 2009. Building a Sustainable Economy. http://www.davidsuzuki.org/Economy/

TTSP 2000. Townsville/Thuringowa Strategy Plan. Framework for managing growth and development. Queensland Government, Department of Communication and information, local government and sport. 62.

Troy P, Holloway D, Pullen S and Bunker R 2003. Embodied and operational energy consumption in the city. Urban policy and research. 21:1, 9-44.

Turner BL and Robbins P 2008. Land-Change Science and Political Ecology: Similarities, Differences, and Implications for Sustainability Science. Annual Review of Environment and Resources. 33:1. 295 - 316.

Waddell EW and Nunn PD 1993. The margin fades. Geographic itineraries in a world of islands. Suva Institute of Pacific Studies.

Walmsley DJ 1988. Urban living, the individual in the city. Longman scientific and technical.

Walmsley DJ and Lewis GJ 1993. People and the environment. Behavioural approaches in human geography. 2nd Ed. Longman.

Wang $\mathrm{JH}$, Koizumi A and Liu X 2007. Advancing sustainable urban development in China. Proceedings of the Institution of Civil Engineers. Municipal Engineer. 161:ME1. 3-10.

Williams A 1992. Transport and the future. In (Ed) BS Hoyle and RD Knowles. Modern transport geography. John Wiley and Sons.

Williams A and Collins D 1997. Petroleum - future possibilities. In (Ed) Australian Academy of technological sciences and engineering. Energy for ever: technological challenges of sustainable growth. 103-116.

Withers CWJ 2007. History and philosophy of geography 2004-2005: biographies, practices, sites. Progress in Human Geography 24:4. 521-549.

Yakubov M 2009. Water for food as food for thought: case study of applying the PODIUMSim model to Uzbekistan. Irrigation and Drainage. 58:1. 17-37.

Yepsen R 2008. Composting and local food merge at urban garden. BioCycle. 49:11. 31- 33. 